\title{
Diversity of parameters in the muscle strength evaluation of Brazilian school children and adolescents: a systematic review
}

\section{Diversidade de parâmetros na avaliação da força muscular de criancas e adolescentes escolares brasileiros: revisão sistemática}

\author{
Tiago Rodrigues de Lima \\ Mikael Seabra Moraes \\ Priscila Custódio Martins ${ }^{1}$ \\ Vladimir Schuindt da Silva ${ }^{2}$ \\ Diego Augusto Santos Silva
}

\begin{abstract}
Muscle strength (MS) is considered important indicative of global health regardless of age or clinical condition. The aim of this study was to summarize evidence from research carried out in Brazil that investigated MS in school children and adolescents, showing the objectives, tests, protocols and quantitative of youngsters who met the health criteria for MS. Systematic review conducted in the PubMed, Web of Science, Scopus, Sportdiscus, LILACS and Scielo databases, with complementary searches in reference lists. In all articles, the risk of bias was analyzed. Of the 15,609 articles initially identified, 27 were included, comprising data from 29,604 children and adolescents. The 27 studies included presented moderate (37\%) and low risk of bias (63\%). Three out of four studies investigating MS in children and adolescents were carried out in southern and southeastern Brazil (77.7\%). It was found that $65.9 \%$ of boys and $58.2 \%$ of girls had adequate levels of MS for health, with results varying from $14.8 \%$ to $66.0 \%$ in girls and from $20.4 \%$ to $76.9 \%$ in boys. Several MS measurement protocols were identified; however, horizontal jump was the most used test to evaluate MS (59.2\%). MS is a physical valence searched in children and adolescents and a variety of protocols are used. In addition, it is necessary to propose MS cutoff points based on health criteria for the accurate estimation of this physical valence in children and adolescents in Brazil.
\end{abstract}

Key words: Epidemiology; Muscle strength; Protocols; Public health.

Resumo - A força muscular (FM) é considerada importante indicativo de saúde global independentemente da idade ou condição clínica. Objetivou-se sumarizar as evidências originárias de pesquisas realizadas no Brasil que investigaram FM em crianças e adolescentes escolares, evidenciando os objetivos, testes, protocolos e o quantitativo de jovens que atenderam os critérios de saúde para FM. Revisão sistemática conduzida nas bases de dados PubMed, Web of Science, Scopus, Sportdiscus, LILACS e Scielo, com buscas complementares em listas de referência. Em todos os artigos, o risco de viés foi analisado. Dos 15.609 artigos inicialmente identificados, 27 foram incluidos, compreendendo dados de 29.604 crianças e adolescentes. Os 27 estudos inclusos apresentaram moderado (37\%) e baixo risco de viés (63\%). Três a cada quatro estudos que investigaram FM em crianças e adolescentes foram provenientes de estados da região sul e sudeste do Brasil (77,7\%). Foi encontrado que 65,9\% de meninos e 58,2\% de meninas apresentavam níveis adequados de FM para saúde, com resultados variando de 14,8\% a 66,0\% nas meninas e de 20,4\% a 76,9\% nos meninos. Diversos protocolos para mensurar FM foram identificados, contudo, o salto horizontal foi o teste mais empregado para avaliar a FM (59,2\%). A FMé uma valência física pesquisada em crianças e adolescentes e uma variedade de protocolos são utilizados. Ainda, se faz necessário a proposição de pontos de corte para FM baseados em critérios de saúde para a acurada estimativa dessa valência física em crianças e adolescentes do Brasil.

Palavras-chave: Epidemiologia; Força muscular; Protocolos; Saúde pública.
1 Federal University of Santa Catarina. Research Center in Kinanthropometry and Human Performance. Florianopolis, SC. Brazil.

2 Federal Institute Catarinense, Fraiburgo, SC, Brazil.

Received: April 21, 2018 Accepted: July 01, 2018 


\section{INTRODUCTION}

Muscle strength (MS) is one of the most important physical valences, since it is an indispensable element in the accomplishment of any type of movement, from the most simple to the most complex, being fundamental to the performance of daily activities, either recreational, domestic or physical performance, considered important indicative of global health regardless of age or clinical condition ${ }^{1}$. In the pediatric population, MS is essential for the improvement of motor skills ${ }^{2}$, and the development of this physical valence is directly related to maturational progression, with higher values for boys compared to girls in all age groups ${ }^{3}$.

Studies with children and adolescents have shown a relationship between MS levels and health prognoses ${ }^{4,5}$. Research conducted with male adolescents in Sweden has found that higher MS levels in adolescence were directly associated with lower risk of premature death from cardiovascular disease in adulthood ${ }^{4}$. Another study conducted with 669 Colombian schoolchildren found that low MS levels were directly associated with higher blood pressure (diastolic and systolic) values, higher HOMA index, and elevated triglyceride and $\mathrm{C}$-reactive protein concentrations ${ }^{5}$.

The evaluation/use of MS is necessary because this physical valence is basic to all the others, is a way to prevent specific damages, is necessary to good appearance, and is one of the elements of physical fitness related to health and performance ${ }^{1}$. However, since there are several types of strength (isometric, isotonic and isokinetic), there are several ways of measuring them ${ }^{1}$. This variety of protocols results in difficulty in comparing results between studies and there is need to compile what has been researched on this topic ${ }^{6}$.

Although several studies conducted in Brazil have investigated the relationship between MS in children and adolescents and related aspects ${ }^{7-9}$, information regarding the objectives addressed, quality of identified results, regional distribution of researches, tests used, classification adopted for the classification of MS levels and discussion of results were not compiled in systematic reviews or official documents intended for sports, health and physical education professionals, so that they can direct professional actions. In this sense, the systematic gathering of information is justified by objectively presenting results of research investigating MS in children and adolescents in Brazil.

The aim of this study was to verify, through a systematic review, the diversity of parameters for MS evaluation in the fulfillment of health criteria of school children and adolescents in Brazil.

\section{METHODOLOGICAL PROCEDURES}

\section{Search strategy}

The systematic review was performed from December 2017 to January 2018 in the following databases: 1) Medical Literature Analysis and Retrieval System Online (MEDLINE), through PubMed; 2) Web of Knowledge 
(WEB of Science); 3) Scopus; 4) Sportdiscus, through the EBSCOhost platform; 5) Latin American and Caribbean Literature in Health Sciences (LILACS); 6) Scientific Electronic Library Online (Scielo).

The investigation of possible articles in databases was carried out using the advanced search tool (searches carried out using "keywords") available in databases based on the construction of blocks of descriptors made by the author. Descriptors were inserted in Portuguese, English and Spanish. The first block (outcome) was composed of MS terms: "muscle strength"; "muscular fitness"; "musculoskeletal fitness"; "resistance training"; "weight training”; "muscle endurance”; "muscle power”; “lower limb strength”; "upper limb strength"; "isometric strength"; "dynamic force"; "force resistance"; "isotonic contraction"; "isometric contraction". The second block was composed of terms related to the target population (children and adolescents): "young adult"; adolescents; young; adolescence; youth; adolescent; children; child; "Pre-school children." The Boolean "OR” operator was used to add in the advanced search at least one word from each block and the "AND" operator to relate the blocks of "keywords" to each other. Further information in relation to the search of studies and descriptors used can be verified in Appendix A.

The risk of bias/methodological quality assessment of studies was independently performed by three reviewers/authors (TRL, PCM, MSM). The instrument used to assess risk of bias/methodological quality was the National Heart, Lung and Blood Institute (NHLBI) ${ }^{10}$ questionnaire for cohort and cross-sectional studies covering 14 criteria to determine the risk of bias/methodological quality of studies. This instrument evaluates the internal validity of studies and includes questions that help in the identification of possible risk of selection bias, information bias, measurement bias and confounders ${ }^{10}$. For each criterion evaluated, scores from 0 "no" and 1 "yes" were assigned, and at the end of the study classification, a total score was assigned to each study based on the number of positive responses to the questionnaire in relation to the total number of questions. Questionnaire questions that could not be answered by the available information and/or which were not applicable to the assessed study and/or aspects that had not been reported were excluded from the calculation to determine the final methodological quality score/risk of bias ${ }^{10}$.

According to the subjective evaluation of the reviewers / authors, studies were classified as having good methodological quality/low risk of bias (final score $\geq 0.70$ ), moderate methodological quality/moderate risk of bias (final score $\geq 0.50$ ), low methodological quality / high risk of bias (final score $<0.50)^{11}$. Three reviewers/authors (TRL, PCM, MSM) applied the methodological quality/risk of bias assessment tool for all studies that met the inclusion criteria. The reviewers/authors' non-agreement regarding the evaluation of a particular study was resolved through a consensus meeting.

The EndNote ${ }^{\circledR}$ X7 bibliographic manager software was used to create specific libraries, which allowed the identification and exclusion of duplicate studies, division and organization of results of each database. 


\section{Eligibility criteria}

Articles were included according to the following criteria: original articles published in journals (review studies, theses, dissertations, abstracts of scientific meetings were excluded); to have measured MS and described in the body of the article, the test/method used to evaluate MS levels, among them: handgrip strength (HGS, isometric force), tests with isokinetic dynamometer (isokinetic force), horizontal jump (HJ, muscle power/ explosive strength), vertical jump (VJ, muscle power/explosive strength), maximum repetition test $(1 \mathrm{MR})$ or medicine ball throw (TMB, muscle power / explosive strength); with a population of Brazilian children and adolescents aged 0-19 years (and/or mean age included in this interval), without specific clinical conditions, without diagnosis of any disease, nonathletes and of both sexes.

Articles that evaluated MS by means of localized muscle strength tests, such as the repetition tests of trunk flexion (abdominal exercises), repetition tests of elbow flexion (support), repetition tests of lumbar resistance and pull-up in the bar were not include in this review.

\section{Article selection process}

The article selection process was performed by two independent reviewers (TRL and MSM). Firstly, articles applying the inclusion criteria by reading titles and abstracts were excluded. Then, the full texts of the selected articles were read in full to determine which studies that met the inclusion criteria would be selected. In case of doubts among researchers regarding the inclusion of articles, a third researcher was consulted (DASS). After selecting the articles that would be included in the review, the studies described in the references of these selected articles were read with the objective of identifying some possible study not identified in the systematic search in databases.

\section{RESULTS}

The systematic search for articles that investigated MS in Brazilian children and adolescents identified 15,609 studies. After evaluating the total of studies by title and abstract, 95 articles had texts analyzed in full. When considering losses $(n=68)$, a total of 33 studies were excluded because the test used did not investigate MS as defined for the present study: [repetition test of trunk flexion $(\mathrm{n}=28)]$, repetition test of elbow flexion "support" $(\mathrm{n}=06)$, pull-up in bar $(\mathrm{n}=04)$, lumbar resistance $(\mathrm{n}=02)$, evaluation of the combination of resistance tests and MS simultaneously $(n=01)]$. The other losses were related to the age group of participants $(n=02)$, to the study topic $(n=21)$, to the special groups evaluated $(n=04)$, the nationality of the investigated population $(n=06)$, and duplicate studies $(n=02)$. Twenty-seven original articles were included for this review (Figure 1).

Regarding the location of these studies, it was identified that the Southern and Southeastern regions of Brazil were those that most published articles on MS in children and adolescents, with 18 studies ${ }^{7-9,12-27}$. 


\section{2 articles selected $(66.9 \%)$}

- 10 articles outside the age group;

- 78 non -subject articles;

- 11 articles made with groups with

special clinical conditions:

13 articles in duplicates;

80 articles made with non

Brazilian population;

68 articles selected $(71.6 \%)$

- 02 age group;

- 21 outside the theme

- 04 articles with special groups;

- 08 articles made with non

Brazilian population;

- 33 type of manifestation of muscle strength measured.
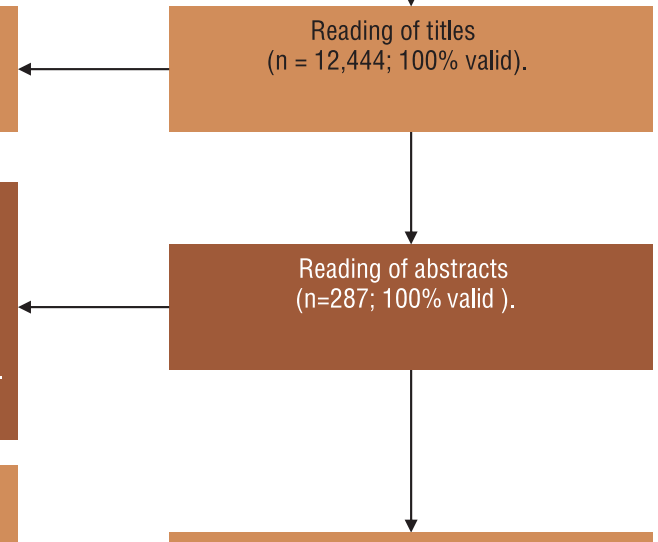

Reading in full

( $n=95,100 \%$ valid).

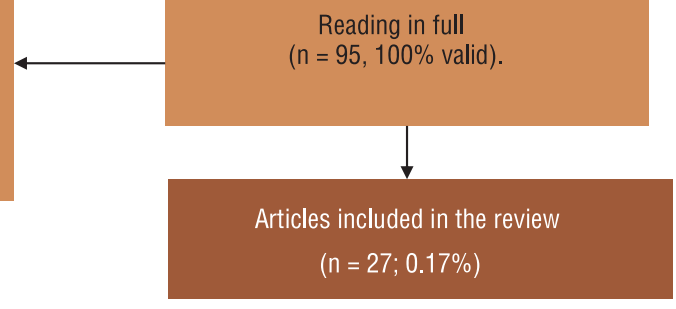

Figure 1. Results of data searches and criteria used in the selection of studies that sought to investigate MS correlates in children and adolescents in Brazil.

Regarding the design of included studies, 22 had cross-section$\mathrm{al}^{3,7-9,14-21,23-25,27-35}$ and five longitudinal design $\mathrm{n}^{12,13,22,26,36}$ (Table 1). The studies covered different primary goals as can be observed in Table 1 ; however, all of them performed MS measurements as defined in the present study.

Table 1: Descriptive characteristics of included studies.

\begin{tabular}{|c|c|c|c|c|}
\hline Reference & Place of study & $\begin{array}{l}\text { Population } \\
\text { (age group) }\end{array}$ & $\begin{array}{l}\text { Sex } \\
(\% W)\end{array}$ & Primary objective of the study \\
\hline \multicolumn{5}{|c|}{ Evidence of longitudinal studies $(n=5)$} \\
\hline Britto et al., ${ }^{12}$ & Ilhabela, SP & $\begin{array}{l}44 \text { school children } \\
(9.5 \text { to } 14.7 \pm 1.87)\end{array}$ & 100 & $\begin{array}{l}\text { To investigate the stability of PF from childhood to adoles- } \\
\text { cence }\end{array}$ \\
\hline Conte et al., ${ }^{13}$ & Sorocaba, SP & $\begin{array}{l}56 \text { school children } \\
\text { (10-17 years old) }\end{array}$ & 62.5 & Influence of body mass on PF in adolescents \\
\hline Biássio et al.. ${ }^{26}$ & Ilhabela, SP & $\begin{array}{l}62 \text { girls } \\
\text { (8-18 years old })\end{array}$ & NA & $\begin{array}{l}\text { Impact of menarche on PF anthropometric and neuromotor } \\
\text { variables }\end{array}$ \\
\hline Da Silva et al., ${ }^{36}$ & Cariri, CE & $\begin{array}{l}294 \text { girls } \\
\text { (8-14 years) }\end{array}$ & NA & $\begin{array}{l}\text { To investigate the stability of PF from childhood to adoles- } \\
\text { cence }\end{array}$ \\
\hline Ferrari et al.., ${ }^{22}$ & Ilhabela, SP & $\begin{array}{l}1,291 \text { students } \\
\text { (10-11 years) }\end{array}$ & NA & $\begin{array}{l}\text { To analyze and compare the changes in PF according to nutri- } \\
\text { tional status and sex in schoolchildren in a period of } 30 \text { years. }\end{array}$ \\
\hline \multicolumn{5}{|c|}{ Evidence from cross-sectional studies $(\mathrm{n}=22)$} \\
\hline Schneider el al., ${ }^{14}$ & Porto Alegre, RS & $\begin{array}{l}57 \text { students } \\
\text { (7-15 years) }\end{array}$ & 49.1 & To compare isometric and isokinetic MS in boys and girls. \\
\hline
\end{tabular}

Continue... 
.. continue

\begin{tabular}{|c|c|c|c|c|}
\hline Reference & Place of study & $\begin{array}{l}\text { Population } \\
\text { (age group) }\end{array}$ & $\begin{array}{l}\text { Sex } \\
(\% W)\end{array}$ & Primary objective of the study \\
\hline Ulbrich et al., ${ }^{15}$ & Curitiba, PR & $\begin{array}{l}275 \text { school children } \\
\text { (6-16 years old) }\end{array}$ & 71.2 & Compare PF according to stages of sexual maturation. \\
\hline Linhares et al., ${ }^{32}$ & Juiz de Fora, MG & $\begin{array}{l}136 \text { school children } \\
(10-14 \text { years) }\end{array}$ & 100 & $\begin{array}{l}\text { To describe how body composition, somatotype, basic } \\
\text { physical qualities, dermatoglyphs and bone age behave in } \\
\text { the various stages of sexual maturation. }\end{array}$ \\
\hline Luguetti et al., ${ }^{16}$ & São Paulo, SP & $\begin{array}{l}3,145 \text { school children } \\
\text { ( } 7-16 \text { years old })\end{array}$ & 50.5 & $\begin{array}{l}\text { Measure PF indicators in children and adolescents, ac- } \\
\text { cording to chronological age and gender, and classify their } \\
\text { performance through normative tables of the PROESP-BR. }\end{array}$ \\
\hline $\begin{array}{l}\text { Silva and Cabral } \\
\text { de Oliveira, }{ }^{3}\end{array}$ & $\begin{array}{l}\text { São Cristóvão, } \\
\text { SE }\end{array}$ & $\begin{array}{l}128 \text { girls } \\
\text { (11-14 years) }\end{array}$ & NA & $\begin{array}{l}\text { Impact of sexual maturation on upper and lower limb } \\
\text { strength in adolescents }\end{array}$ \\
\hline Ferreira et al., ${ }^{17}$ & São Paulo & $\begin{array}{l}199 \text { school children } \\
\text { (6-19 years) }\end{array}$ & 40.7 & Determine and compare HGS values and pinch. \\
\hline Arruda et al., ${ }^{19}$ & Londrina, PR & $\begin{array}{l}10 \text { students } \\
(10.2 \pm 2.2)\end{array}$ & 100 & $\begin{array}{l}\text { To analyze the relationship between } 1 \mathrm{MR} \text { tests with body } \\
\text { composition, anthropometric variables, neuromotor tests } \\
\text { and biological maturation. }\end{array}$ \\
\hline Santos et al.., ${ }^{33}$ & $\begin{array}{l}\text { Vitória de Santo } \\
\text { Antão, PE }\end{array}$ & $\begin{array}{l}356 \text { school children } \\
\text { ( } 7-10 \text { years) }\end{array}$ & 55.0 & To identify the influence of low birth weight on PF. \\
\hline Lopes et al., ${ }^{7}$ & Maringá, PR & $\begin{array}{l}36 \text { girls } \\
\text { (13-17 years old) }\end{array}$ & NA & $\begin{array}{l}\text { To compare LLS and ULS among obese and non-obese } \\
\text { adolescents and to verify the association of MS with anthro- } \\
\text { pometric variables and body composition. }\end{array}$ \\
\hline Minatto et al. ${ }^{27}$ & Cascavel, PR & $\begin{array}{l}1,531 \text { school children } \\
\text { (6-17 years) }\end{array}$ & 100 & $\begin{array}{l}\text { To estimate the prevalence of high adiposity and its associa- } \\
\text { tion with musculoskeletal fitness, by economic level, in male } \\
\text { children and adolescents. }\end{array}$ \\
\hline Freitas et al., ${ }^{35}$ & $\begin{array}{l}\text { Montes Claros, } \\
\text { MG }\end{array}$ & $\begin{array}{l}2,040 \text { girls } \\
\text { (8-15.9 years) }\end{array}$ & NA & $\begin{array}{l}\text { To identify the relationship between biological maturation, } \\
\text { body morphology and physical performance. }\end{array}$ \\
\hline Matsudo et al., ${ }^{20}$ & Ilhabela, SP & $\begin{array}{l}233 \text { school children } \\
\text { (10-17 years old) }\end{array}$ & 54.9 & $\begin{array}{l}\text { To examine the association between FPM and PF in children } \\
\text { and adolescents of different stages of sexual maturation. }\end{array}$ \\
\hline De Farias et al.. ${ }^{21}$ & Jacarezinho, PR & $\begin{array}{l}21 \text { students } \\
\text { (12-16 years) }\end{array}$ & 57.1 & $\begin{array}{l}\text { Correlating MS with anthropometric indicators, matura- } \\
\text { tional stage, neuromotor tests in adolescents. }\end{array}$ \\
\hline Barbosa et al., ${ }^{28}$ & $\begin{array}{l}\text { Muzambinho, } \\
\text { MG }\end{array}$ & $\begin{array}{l}122 \text { school children } \\
(9.9 \pm 1.3)\end{array}$ & 53.2 & $\begin{array}{l}\text { To investigate the association between PA and PF indicators } \\
\text { with clusters of metabolic risk factors. }\end{array}$ \\
\hline Mello et al., ${ }^{30}$ & $\begin{array}{l}13 \text { Brazilian } \\
\text { states and FD }\end{array}$ & $\begin{array}{l}8,750 \text { school children } \\
\text { (7-17 years old) }\end{array}$ & ND & $\begin{array}{l}\text { To outline the PF profile related to the sports performance of } \\
\text { Brazilian children and adolescents. }\end{array}$ \\
\hline Brandão et al.., ${ }^{29}$ & Cuiabá, MT & $\begin{array}{l}414 \text { school children } \\
\text { (15-17 years) }\end{array}$ & 55.3 & $\begin{array}{l}\text { Create index for PF tests based on the parameters of } \\
\text { PROESP-BR. }\end{array}$ \\
\hline Pires et al., ${ }^{23}$ & $\begin{array}{l}\text { Santa Cruz do } \\
\text { Sul, RS }\end{array}$ & $\begin{array}{l}751 \text { school children } \\
\text { ( } 7-17 \text { years old) }\end{array}$ & 41.5 & $\begin{array}{l}\text { To test association between school dislocation and PF } \\
\text { related to motor performance in schoolchildren. }\end{array}$ \\
\hline Nunes et al., ${ }^{24}$ & São José, SC & $\begin{array}{l}1,117 \text { school children } \\
\text { (14-19 years old) }\end{array}$ & ND & $\begin{array}{l}\text { To identify the relationship between PF with changes in } \\
\text { blood pressure (systolic and diastolic). }\end{array}$ \\
\hline Lima and Silva, ${ }^{8}$ & São José, SC & $\begin{array}{l}866 \text { school children } \\
\text { (14-19 years) }\end{array}$ & 46.8 & $\begin{array}{l}\text { To identify the relationship between clusters of PF indicators } \\
\text { and sociodemographic and lifestyle factors. }\end{array}$ \\
\hline Hobolt et al.. ${ }^{31}$ & $\begin{array}{l}\text { Lago de Itaipu, } \\
\text { RJ }\end{array}$ & $\begin{array}{l}5,962 \text { school children } \\
\text { (6-17.9 years) }\end{array}$ & 49.2 & Develop standards to classify PF \\
\hline $\begin{array}{l}\text { Silva and Mar- } \\
\text { tins }^{25}\end{array}$ & São José, SC & $\begin{array}{l}922 \text { school children } \\
\text { (14-19 years) }\end{array}$ & 47.1 & $\begin{array}{l}\text { To investigate the impact of physical growth, body fat and } \\
\text { lifestyle on cardiorespiratory fitness and MS in pubertal and } \\
\text { pubescent adolescents. }\end{array}$ \\
\hline Silva et al., ${ }^{9}$ & $\begin{array}{l}\text { Florianópolis, } \\
\text { SC }\end{array}$ & $\begin{array}{l}636 \text { school children } \\
\text { (14-19 years) }\end{array}$ & 36.1 & $\begin{array}{l}\text { To estimate the prevalence of low levels of HGS and related } \\
\text { sociodemographic and lifestyle factors. }\end{array}$ \\
\hline
\end{tabular}

W: Womem; Mean; \pm : standard deviation; ND: not described; MA: Mato Grosso; FD: Federal District; MG: Minas Gerais; CE: Ceará; RJ: Rio de Janeiro; PR: Paraná, SP: São Paulo; RS: Rio Grande do Sul; SC: Santa Catarina; SE: Sergipe; MS: muscle strength; HGS: Handgrip strength; 1MR: maximum repetition; BC: body composition; PA: physical activity; PF: physical fitness; NA: not applicable; ULS: upper limb strength; LLS: Iower limb strength; PROESP-BR: Project Sports Brazil - Brazil;

No study was classified with low methodological quality / high risk of bias. Moderate methodological quality/moderate risk of bias was verified in ten studies $(37.0 \%)^{7,12,13,15,19,21,23,26,28,29}$, while seventeen studies 
$(67.0 \%)^{3,8,9,14,16,17,20,22,24,25,27,30-33,35,36}$ were classified with high methodological quality / low risk of bias (Table 2).

Table 2. Bias risk assessment of included studies.

\begin{tabular}{|c|c|c|c|c|c|c|c|c|c|c|c|c|c|c|c|c|}
\hline Author & Q1 & Q2 & Q3 & Q4 & Q5 & Q6 & Q7 & Q8 & Q9 & Q10 & Q11 & Q12 & Q13 & Q14 & Final score ${ }^{\star}$ & Ranking \\
\hline Britto et al., ${ }^{12}$ & 1 & 1 & 0 & 1 & 0 & 1 & 1 & ND & 1 & 1 & ND & 0 & ND & 0 & 0.63 & Moderate risk of bias \\
\hline Conte et al., ${ }^{13}$ & 1 & 1 & ND & 0 & 0 & 1 & ND & ND & 1 & 1 & 1 & 0 & NR & 0 & 0.60 & Moderate risk of bias \\
\hline Schneider et al. ${ }^{14}$ & 1 & 1 & 0 & 1 & 0 & ND & ND & 1 & 1 & 1 & 1 & 0 & ND & 1 & 0.72 & Low risk of bias \\
\hline Biassio et al.. ${ }^{26}$ & 1 & 1 & 0 & 1 & 1 & 1 & 1 & ND & 1 & 1 & 1 & 0 & 0 & 0 & 0.69 & Moderate risk of bias \\
\hline Ulbrich et al.., & 1 & 1 & NR & 0 & 0 & ND & ND & ND & 1 & 1 & 1 & 0 & ND & ND & 0.62 & Moderate risk of bias \\
\hline Linhares et al., ${ }^{32}$ & 1 & 1 & ND & 1 & ND & ND & 1 & ND & 1 & 0 & 1 & 0 & ND & 0 & 0.70 & Low risk of bias \\
\hline Luguetti et al., ${ }^{16}$ & 1 & 1 & NR & 1 & 1 & ND & ND & 1 & 1 & 0 & 1 & 0 & ND & 0 & 0.70 & Low risk of bias \\
\hline $\begin{array}{l}\text { Silva and Cabral de } \\
\text { Oliveira, }{ }^{3}\end{array}$ & 1 & 1 & 1 & 1 & 1 & ND & ND & ND & 1 & ND & 1 & 0 & ND & 0 & 0.77 & Low risk of bias \\
\hline Arruda et al.., ${ }^{19}$ & 1 & 0 & ND & 1 & 0 & ND & ND & ND & 1 & ND & 1 & 0 & ND & 0 & 0.50 & Moderate risk of bias \\
\hline Ferreira et al., ${ }^{17}$ & 1 & 1 & 0 & 1 & 1 & 0 & 0 & 1 & 1 & NA & 1 & NA & NA & 1 & 0.73 & Low risk of bias \\
\hline Da Silva et al., ${ }^{36}$ & 1 & 1 & 1 & 1 & 1 & 1 & 1 & NA & 1 & 1 & 1 & 0 & NR & 0 & 0.83 & Low risk of bias \\
\hline Lopes et al., ${ }^{7}$ & 1 & 1 & 0 & 1 & 0 & 0 & 0 & 1 & 1 & NA & 1 & NA & NA & 1 & 0.64 & Moderate risk of bias \\
\hline Santos et al., ${ }^{33}$ & 1 & 1 & 1 & 1 & 1 & 0 & 0 & 1 & 1 & NA & 1 & NA & NA & 1 & 0.82 & Low risk of bias \\
\hline Freitas et al., ${ }^{35}$ & 1 & 1 & NR & 1 & 0 & 0 & 0 & 1 & 1 & NA & 1 & NA & NA & 1 & 0.70 & Low risk of bias \\
\hline Matsudo et al., ${ }^{20}$ & 1 & 1 & NR & 1 & 1 & 0 & 0 & 1 & 1 & NA & 1 & NA & NA & 1 & 0.80 & Low risk of bias \\
\hline Minatto et al., ${ }^{27}$ & 1 & 1 & 1 & 1 & 1 & 0 & 0 & 1 & 1 & NA & 1 & NA & NA & 1 & 0.82 & Low risk of bias \\
\hline Farias et al., ${ }^{21}$ & 1 & 1 & NR & 1 & 0 & 0 & 0 & 1 & 1 & NA & 1 & NA & NA & 0 & 0.60 & Moderate risk of bias \\
\hline Ferrari et al., ${ }^{22}$ & 1 & 1 & 1 & 0 & 1 & 1 & 1 & 1 & 0 & NA & 0 & NR & 1 & 1 & 0.75 & Low risk of bias \\
\hline Barbosa et al., ${ }^{28}$ & 1 & 1 & NR & 1 & NR & 0 & 0 & 1 & 1 & NA & 1 & NA & NA & 0 & 0.66 & Moderate risk of bias \\
\hline Brandão et al., ${ }^{29}$ & 1 & 1 & 1 & 1 & NR & 0 & 0 & 1 & 0 & NA & 1 & NA & NA & 0 & 0.60 & Moderate risk of bias \\
\hline Mello et al., ${ }^{30}$ & 1 & 1 & 1 & 1 & 1 & 0 & 0 & 1 & 1 & NA & 1 & NA & NA & 1 & 0.81 & Low risk of bias \\
\hline Lima and Silva, ${ }^{8}$ & 1 & 1 & 1 & 1 & 1 & 0 & 0 & 1 & 1 & NA & 1 & NA & NA & 1 & 0.81 & Low risk of bias \\
\hline Hobold et al., ${ }^{31}$ & 1 & 1 & 1 & 1 & 1 & 0 & 0 & 1 & 1 & NA & 1 & NA & NA & 1 & 0.81 & Low risk of bias \\
\hline Nunes et al.. ${ }^{24}$ & 1 & 1 & 1 & 1 & 1 & 0 & 0 & 1 & 1 & NA & 1 & NA & NA & 1 & 0.81 & Low risk of bias \\
\hline Pires et al.., ${ }^{23}$ & 1 & 1 & NR & 1 & NR & 0 & 0 & 1 & 1 & NA & 1 & NA & NA & 0 & 0.66 & Moderate risk of bias \\
\hline Silva and Martins, ${ }^{25}$ & 1 & 1 & 1 & 1 & 1 & 0 & 0 & 1 & 1 & NA & 1 & NA & NA & 1 & 0.81 & Low risk of bias \\
\hline Silva et al., ${ }^{9}$ & 1 & 1 & 1 & 1 & 1 & 0 & 0 & 1 & 1 & NA & 1 & NA & NA & 1 & 0.81 & Low risk of bias \\
\hline
\end{tabular}

ND. Can not be determined; NR. Not reported; NA. Not applicable; 0 . No; 1 . Yes; $\geq 0.70$ : low risk of bias; $\geq 0.50$ : moderate risk of bias; $<0.50$ high risk of bias; ${ }^{*}$ to determine the total score, the following equation was considered: (total of positive answers / total of questions considered for that study).

MS was investigated in fourteen different ways. HJ was used to identify MS levels in 16 studies $^{12,13,15,16,19-21,23,27,29-33,35,36}$; in 15 studies, MS was investigated through $\mathrm{HGS}^{3,8,9,12,15,17,20,22,24-26,28,33,35,36}$; in four studies, vertical jump without the aid of arms (VJWAA) was used to evaluate $\mathrm{MS}^{12,20,22,26}$; in four other studies, TMB was used ${ }^{16,23,29,30}$; in two studies the isokinetic strength of knee extensors (IFKE) was used as a reference for $\mathrm{MS}^{14,21}$; in two other studies, MS was investigated through vertical jump using arms (VJUA) ${ }^{14,21}$; the maximal repetition in the horizontal bench press $(1 \mathrm{MRBP})$ and a maximal repetition in the leg press (1MRLP) tests were used to measure MS levels in one study ${ }^{7}$; the tests of a maximal repetition in the extensor table (1MRET) and a maximum repetition in the biceps curl $(1 \mathrm{MRBC})$ thread were used in another study ${ }^{19}$; isokinetic strength 
of elbow flexors (IFE), isometric strength of the elbow flexors (ISMFE), and isometric strength of the knee extensors (ISMKE) tests were used to measure MS in one study ${ }^{14}$. In addition, the isokinetic strength test of knee flexors (IFKF) was also used ${ }^{21}$ (Table 3).

Table 3. Specific characteristics of included studies.

\begin{tabular}{|c|c|c|c|c|}
\hline References & $\begin{array}{l}\text { Number of evaluated } \\
\text { for MS; Follow-up time }\end{array}$ & $\begin{array}{l}\text { Test used to } \\
\text { evaluate MS }\end{array}$ & $\begin{array}{l}\text { Cutoff value; Mean values of MS } \\
\text { according to sex }\end{array}$ & $\begin{array}{l}\text { Statistical tests used; } \\
\text { Values of the analyzes }\end{array}$ \\
\hline \multicolumn{5}{|c|}{ Evidence of longitudinal studies, $\mathrm{n}=5$} \\
\hline Britto et al., ${ }^{12}$ & $44 ; 5.1$ years & $\begin{array}{l}\text { VJWAA; VJUA; } \\
\text { HJ; HGS }\end{array}$ & N.U; N.D. & $\begin{array}{l}\text { Correlation; Determination } \\
\text { coefficient }\end{array}$ \\
\hline Conte et al., ${ }^{13}$ & $56 ; 2$ years & $\mathrm{HJ}$ & 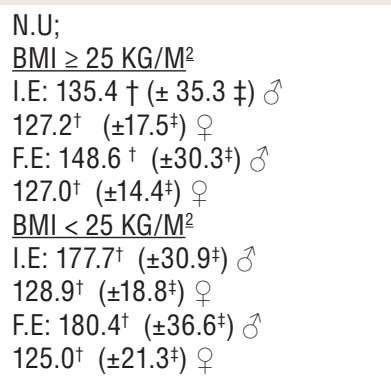 & Comparison of proportions \\
\hline Biassio et al., ${ }^{26}$ & $62 ; 5$ years & HGS; VJWAA & 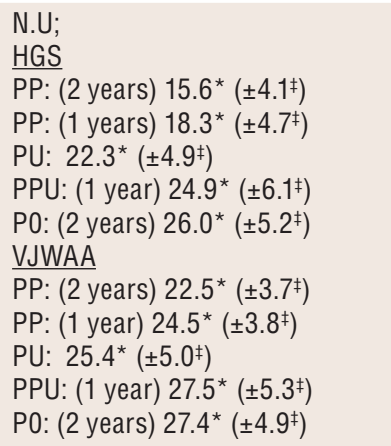 & ANOVA \\
\hline Da silva et al.., ${ }^{36}$ & $294 ; 3$ years & HGS; HJ & N.U; N.D; & $\begin{array}{l}\text { Foulkes \& Davies coef- } \\
\text { ficient ÿ (self-correlation) }\end{array}$ \\
\hline Ferrari et al., ${ }^{22}$ & 1291 & HGS; VJWAA & 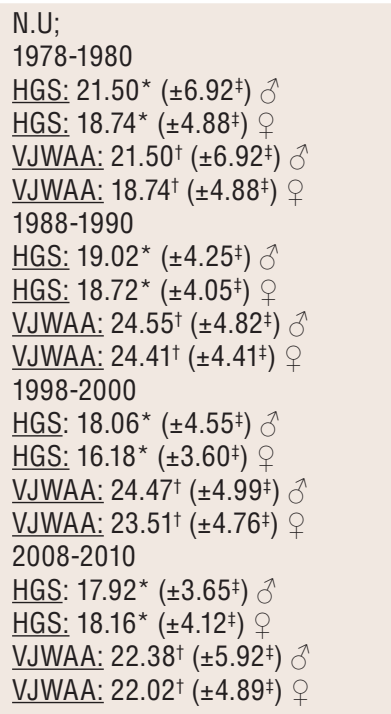 & ANOVA \\
\hline
\end{tabular}




\begin{tabular}{|c|c|c|c|c|}
\hline References & $\begin{array}{l}\text { Number of evaluated } \\
\text { for MS; Follow-up time }\end{array}$ & $\begin{array}{l}\text { Test used to } \\
\text { evaluate MS }\end{array}$ & $\begin{array}{l}\text { Cutoff value; Mean values of MS } \\
\text { according to sex }\end{array}$ & $\begin{array}{l}\text { Statistical tests used; } \\
\text { Values of the analyzes }\end{array}$ \\
\hline Scheneider et al., ${ }^{14}$ & 57 & $\begin{array}{l}\text { IFE; IFKE; } \\
\text { ISMFE; ISMKE; }\end{array}$ & 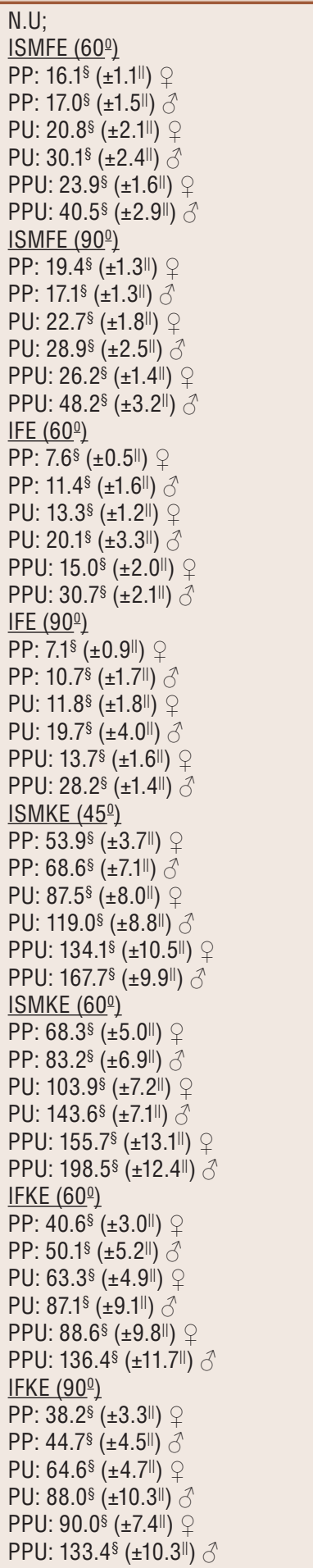 & ANOVA \\
\hline
\end{tabular}


.. continue

\begin{tabular}{|c|c|c|c|c|}
\hline References & $\begin{array}{l}\text { Number of evaluated } \\
\text { for MS; Follow-up time }\end{array}$ & $\begin{array}{l}\text { Test used to } \\
\text { evaluate MS }\end{array}$ & $\begin{array}{l}\text { Cutoff value; Mean values of MS } \\
\text { according to sex }\end{array}$ & $\begin{array}{l}\text { Statistical tests used; } \\
\text { Values of the analyzes }\end{array}$ \\
\hline Ulbrich et al., ${ }^{15}$ & 275 & HGS; HJ & 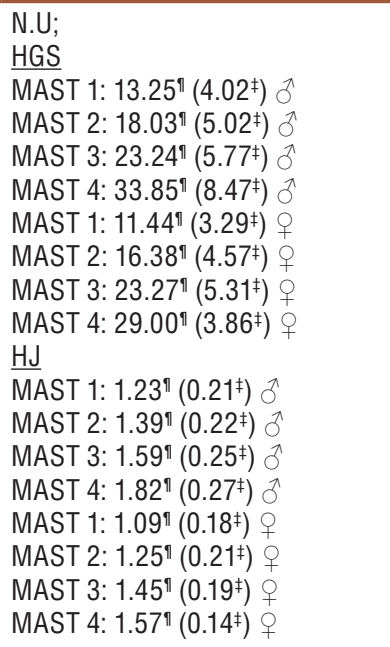 & ANOVA \\
\hline Linhares et al., ${ }^{32}$ & 136 & HJ & N.D; N.U & ANOVA \\
\hline Luguetti et al., ${ }^{16}$ & 3145 & HJ; TMB & 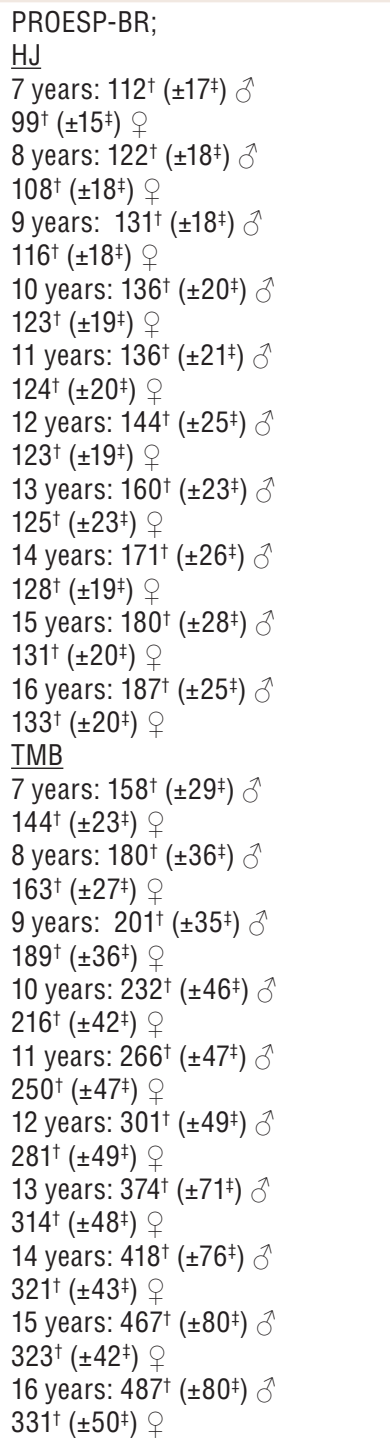 & ANOVA \\
\hline
\end{tabular}




\begin{tabular}{|c|c|c|c|c|}
\hline References & $\begin{array}{l}\text { Number of evaluated } \\
\text { for MS; Follow-up time }\end{array}$ & $\begin{array}{l}\text { Test used to } \\
\text { evaluate MS }\end{array}$ & $\begin{array}{l}\text { Cutoff value; Mean values of MS } \\
\text { according to sex }\end{array}$ & $\begin{array}{l}\text { Statistical tests used; } \\
\text { Values of the analyzes }\end{array}$ \\
\hline $\begin{array}{l}\text { Silva and Cabral de } \\
\text { Oliveira, }{ }^{3}\end{array}$ & 128 & HGS; VJUA & $\begin{array}{l}\text { N.U; } \\
\text { HGS } \\
\text { NM: } 17.8^{\star}\left( \pm 4.4^{\ddagger}\right) \\
\text { MT: } 21.5^{\star}\left( \pm 3.9^{\ddagger}\right) \\
\text { VJUA } \\
\text { NM: } 23.7^{\dagger}\left( \pm 6.7^{\ddagger}\right) \\
\text { MT: } 24.1^{\dagger}\left( \pm 6.7^{\ddagger}\right)\end{array}$ & ANCOVA \\
\hline Arruda et al.. ${ }^{19}$ & 10 & $\begin{array}{l}\text { HJ; 1MRET; } \\
\text { 1MRBC }\end{array}$ & $\begin{array}{l}\text { N.U; } \\
\text { 1MRET: } 21.6^{*}\left( \pm 6.5^{\ddagger}\right) \\
\text { 1MRBC: } 14.8^{*}\left( \pm 3.9^{\ddagger}\right)\end{array}$ & Correlation \\
\hline Ferreira et al., ${ }^{17}$ & 199 & HGS & 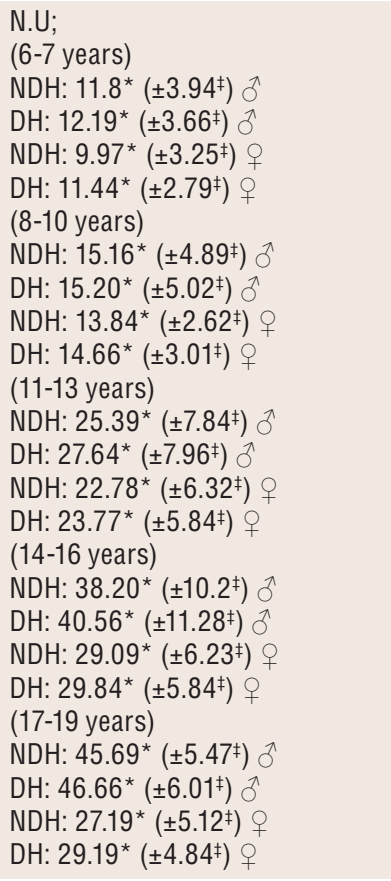 & $\begin{array}{l}\text { Linear Regression with } \\
\text { mixed effects }\end{array}$ \\
\hline Lopes et al., ${ }^{7}$ & 36 & 1MRBP; 1MRLP & N.U; N.D & Multiple linear regression \\
\hline Santos et al., ${ }^{33}$ & 356 & HGS; HJ & $\begin{array}{l}\text { N.U; } \\
\text { NWB } \\
\text { HGS (D): } 14.0^{*}\left( \pm 0.15^{\prime \prime}\right) \\
\text { HGS (E): } 13.3^{*}\left( \pm 0.16^{\prime \prime}\right) \\
\text { HJ: } 108.7^{\dagger}\left( \pm 1.1^{\prime \prime}\right) \\
\text { LWB } \\
\text { HGS (D): } 12.9^{*}\left( \pm 0.25^{\prime \prime}\right) \\
\text { HGS (E): } 12.4^{*}( \pm 0.26 ") \\
\text { HJ: } 108.0^{\dagger}\left( \pm 1.8^{\prime \prime}\right)\end{array}$ & ANCOVA \\
\hline Freitas et al., ${ }^{35}$ & 2040 & HGS; HJ & $\begin{array}{l}\text { N.U; } \\
\text { HGS } \\
\text { LM: } 22.70^{\star}\left( \pm 5.18^{\ddagger}\right) \\
\text { NM: } 18.87^{\star}\left( \pm 6.78^{\ddagger}\right) \\
\text { EM: } 16.84^{\star}\left( \pm 6.10^{\ddagger}\right) \\
\text { HJ } \\
\text { LM: } 125.25^{\dagger}\left( \pm 25.41^{\ddagger}\right) \\
\text { NM: } 114.35^{\dagger}\left( \pm 25.53^{\ddagger}\right) \\
\text { EM: } 106.39^{\dagger}\left( \pm 27.26^{\ddagger}\right)\end{array}$ & ANOVA \\
\hline
\end{tabular}

Continue.. 
... continue

\begin{tabular}{|c|c|c|c|c|}
\hline References & $\begin{array}{l}\text { Number of evaluated } \\
\text { for MS; Follow-up time }\end{array}$ & $\begin{array}{l}\text { Test used to } \\
\text { evaluate MS }\end{array}$ & $\begin{array}{l}\text { Cutoff value; Mean values of MS } \\
\text { according to sex }\end{array}$ & $\begin{array}{l}\text { Statistical tests used; } \\
\text { Values of the analyzes }\end{array}$ \\
\hline Matsudo et al., ${ }^{20}$ & 233 & $\begin{array}{l}\text { HGS; HJ; } \\
\text { VJWAA }\end{array}$ & $\begin{array}{l}<372.78^{\S} / \geq 372.79^{\S} \\
\text { HGS } \\
<372.78 \S: 284.5^{\S}\left( \pm 5.3^{\| \prime}\right) \\
\geq 372.79 \S: 500.4^{\S}\left( \pm 12.6^{\|}\right) \\
\text {VJWAA } \\
<372.78^{\S}: 23.3^{\dagger}\left( \pm 0.6^{\prime \prime}\right) \\
\geq 372.79^{\S}: 27.8^{\dagger}\left( \pm 0.6^{\| \prime}\right) \\
\underline{\text { HJ }} \\
<372.78^{\S}: 111.5^{\dagger}\left( \pm 2.0^{\| \prime}\right) \\
\geq 372.79^{\S}: 138.7^{\dagger}\left( \pm 3.0^{\|}\right)\end{array}$ & Multiple linear regression \\
\hline Minatto et al., ${ }^{27}$ & 1469 & HJ & Tertiles; N.D; & Binary Logistic Regression \\
\hline Farias et al.. ${ }^{21}$ & 21 & IFKF; IFKE; HJ & 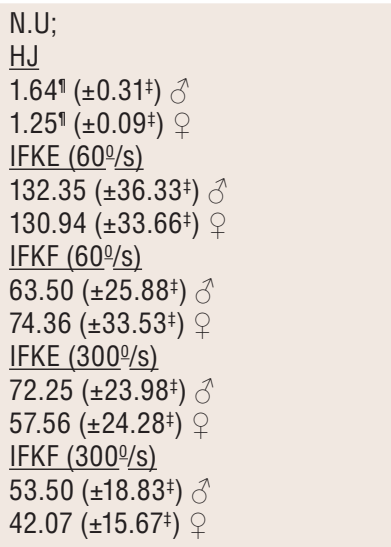 & $\begin{array}{l}\text { Correlation; Student's } \\
\text { t-test. }\end{array}$ \\
\hline Barbosa et al., ${ }^{28}$ & 122 & HGS & N.U; N.D & Poisson Regression \\
\hline Brandão et al., ${ }^{29}$ & 414 & TMB; HJ & PROESP-BR; N.D; & $\begin{array}{l}\text { Multivariate factorial } \\
\text { analysis }\end{array}$ \\
\hline Mello et al.., ${ }^{30}$ & 8750 & TMB; HJ & $\begin{array}{l}\text { PROESP-BR; } \\
\text { HJ } \\
7 \text { years: } 120.78^{\dagger}\left( \pm 26.37^{\ddagger}\right) \\
8 \text { years: } 124.78^{\dagger}\left( \pm 25.23^{\ddagger}\right) \\
9 \text { years: } 130.17^{\dagger}\left( \pm 26.02^{\ddagger}\right) \\
10 \text { years: } 137.71^{\dagger}\left( \pm 24.89^{\ddagger}\right) \\
11 \text { years: } 145.64^{\dagger}\left( \pm 30.05^{\ddagger}\right) \\
12 \text { years: } 154.74^{\dagger}\left( \pm 29.39^{\ddagger}\right) \\
13 \text { years: } 165.94^{\dagger}\left( \pm 29.78^{\ddagger}\right) \\
14 \text { years: } 180.41^{\dagger}\left( \pm 32.12^{\ddagger}\right) \\
15 \text { years: } 186.13^{\dagger}\left( \pm 30.80^{\ddagger}\right) \\
16 \text { years: } 190.90^{\dagger}\left( \pm 29.31^{\ddagger}\right) \\
17 \text { years: } 194.80^{\dagger}\left( \pm 34.80^{\ddagger}\right) \\
\text { TMB } \\
7 \text { years: } 164.95^{\dagger}\left( \pm 49.56^{\ddagger}\right) \\
8 \text { years: } 189.23^{\dagger}\left( \pm 46.82^{\ddagger}\right) \\
9 \text { years: } 212.64^{\dagger}\left( \pm 50.38^{\ddagger}\right) \\
10 \text { years: } 234.42^{\dagger}\left( \pm 55.83^{\ddagger}\right) \\
11 \text { years: } 261.89^{\dagger}\left( \pm 64.84^{\ddagger}\right) \\
12 \text { years: } 305.16^{\dagger}\left( \pm 74.86^{\ddagger}\right) \\
13 \text { years: } 346.96^{\dagger}\left( \pm 90.86^{\ddagger}\right) \\
14 \text { years: } 417.18^{\dagger}\left( \pm 101.78^{\ddagger}\right) \\
15 \text { years: } 474.33^{\dagger}\left( \pm 95.26^{\ddagger}\right) \\
16 \text { years: } 496.13^{\dagger}\left( \pm 102.31^{\ddagger}\right) \\
17 \text { years: } 522.46^{\dagger}\left( \pm 97.80^{\ddagger}\right)\end{array}$ & Descriptive statistics \\
\hline Lima and Silva, ${ }^{8}$ & 866 & HGS & CSEP; N.D; & $\begin{array}{l}\text { Multinomial logistic } \\
\text { regression }\end{array}$ \\
\hline
\end{tabular}




\begin{tabular}{|c|c|c|c|c|}
\hline References & $\begin{array}{l}\text { Number of evaluated } \\
\text { for MS; Follow-up time }\end{array}$ & $\begin{array}{l}\text { Test used to } \\
\text { evaluate MS }\end{array}$ & $\begin{array}{l}\text { Cutoff value; Mean values of MS } \\
\text { according to sex }\end{array}$ & $\begin{array}{l}\text { Statistical tests used; } \\
\text { Values of the analyzes }\end{array}$ \\
\hline Hobold et al., ${ }^{31}$ & 5962 & $\mathrm{HJ}$ & 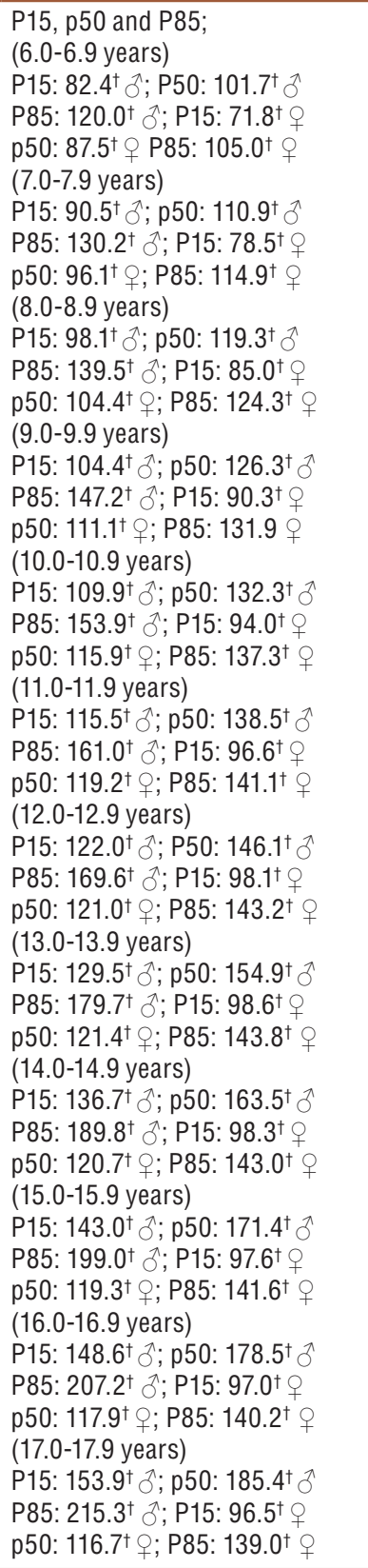 & $\begin{array}{l}\text { Percentage curves and } \\
\text { Student's t-test }\end{array}$ \\
\hline Nunes et al., ${ }^{24}$ & 1117 & HGS & N.U; N.D. & Multiple linear regression \\
\hline Pires et al., ${ }^{23}$ & 751 & TMB; HJ & 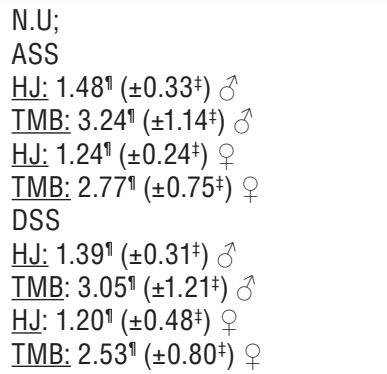 & Student t test \\
\hline
\end{tabular}

Continue... 


\begin{tabular}{|c|c|c|c|c|}
\hline References & $\begin{array}{l}\text { Number of evaluated } \\
\text { for MS; Follow-up time }\end{array}$ & $\begin{array}{l}\text { Test used to } \\
\text { evaluate MS }\end{array}$ & $\begin{array}{l}\text { Cutoff value; Mean values of MS } \\
\text { according to sex }\end{array}$ & $\begin{array}{l}\text { Statistical tests used; } \\
\text { Values of the analyzes }\end{array}$ \\
\hline Silva and $\&$ Martins ${ }^{25}$ & 1132 & HGS & 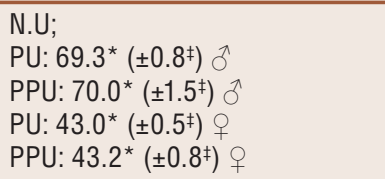 & ANCOVA \\
\hline Silva et al.., ${ }^{9}$ & 636 & HGS & CSEP; N.D. & Binary Logistic Regression \\
\hline
\end{tabular}

MS: muscle strength; VJWAA: vertical jump without the aid of arms ; VJUA: vertical jump using arms; HJ: horizontal jump; HGS: handgrip strength; N.U: not used; N.D: not described; PP: pre-pubertal; PU: pubertal ; PPU: post-pubertal; I.E: Initial evaluation; F.E: final evaluation; IFE: isokinetic flexion of elbows; IFKE: isokinetic force knee extension; IFKF: isokinetic force knee flexion; ISMFE: isometric flexion of elbows; ISMKE: isometric knee extension; BMI: body mass index; TMB: throw medicine-ball; PROESP-BR: Projeto Esporte Brasil; NM: Not mature; MT: matured; LM: late maturation; NM: normal maturation; EM: early maturation; ${ }^{\lambda}$ : boys; : $:$ girls; * expressed in kilograms; ${ }^{\dagger}$ : values expressed in centimeters; ${ }^{*}$ : Standard deviation; $\$$ : values expressed in Newtons; $\|$ : standard error; $"$ : values expressed in meters; 1MRET: maximum repetition extender table; 1MRBC: maximum repetition biceps curl; 1MRBP: maximum repetition bench press; 1 MRLP: maximum repetition leg press; NDH: non-dominant hand; DH: dominant hand; NWB: normal weight at birth; LWB: low weight at birth; s: seconds; CSEP: Canadian Society of Exercise and Physiology; P15: percentile 15; p50: percentile 50; P85: percentile 85; ASS: active shift to school; DSS: passive shift to school; MAST: maturational stage.

Table 4 shows studies that classified MS as adequate or inadequate for health based on some physical test battery ${ }^{8,9,16,29,30}$. Five studies did this type of classification and used three different physical tests (e.g., HJ, TMB and HGS). Three studies used two different tests in the same sample (e.g., HJ, $\mathrm{TMB})^{16,29,30}$. The physical test batteries PROESP/BR ${ }^{37}$ and $\mathrm{CSEP}^{6}$ were used in these studies. A total of 13,028 subjects aged 7-19 years were surveyed when computing all these studies and this resulted in $65.9 \%$ of boys and $58.2 \%$ of girls with adequate MS levels for health throughout Brazil.

Table 4. Characteristics of studies that classified muscle strength in categories based on test batteries that have health criteria.

\begin{tabular}{|c|c|c|c|c|c|c|}
\hline Authors & Local & Sample & $\begin{array}{l}\text { Age group } \\
\text { (years) }\end{array}$ & $\begin{array}{l}\text { Test to measure } \\
\text { muscle strength }\end{array}$ & $\begin{array}{l}\text { Percentage of subjects } \\
\text { classified as having ad- } \\
\text { equate muscle strength }\end{array}$ & $\begin{array}{l}\text { Reference for the } \\
\text { classification of } \\
\text { muscular strength }\end{array}$ \\
\hline \multirow[t]{2}{*}{ Luguetti et al., ${ }^{16}$} & São Paulo, SP & $\begin{array}{c}3,145 \\
\text { (1,590 boys, } \\
1,555 \text { girls })\end{array}$ & $7-16$ & - HJ; & $\begin{array}{l}54 \% \text { of the boys } \\
(n=859) \\
43 \% \text { of the girls } \\
(n=669)\end{array}$ & PROESP/BR $\S^{37}$ \\
\hline & & & & - TMB. & $\begin{array}{c}67 \% \text { of boys } \\
(n=1,065) ; \\
66 \% \text { of the girls } \\
(n=1,026)\end{array}$ & \\
\hline \multirow[t]{2}{*}{ Brandão et al., ${ }^{29}$} & Cuiabá, MT & $\begin{array}{c}414 \\
\text { (229 boys, } \\
185 \text { girls) }\end{array}$ & $15-17$ & - HJ; & $\begin{array}{l}75.1 \% \text { of the boys } \\
\quad(n=172) ; \\
63.2 \% \text { of the girls } \\
(n=117)\end{array}$ & PROESP/BR $\S^{37}$ \\
\hline & & & & - TMB. & $\begin{array}{l}76.9 \% \text { of the boys } \\
(n=176) ; \\
63.8 \% \text { of the girls } \\
(n=118)\end{array}$ & \\
\hline \multirow[t]{2}{*}{ Mello et al., ${ }^{30}$} & $\begin{array}{l}13 \text { states of } \\
\text { Brazil and } \\
\text { the Federal } \\
\text { District }\end{array}$ & $\begin{array}{c}8,280 \\
\text { (4,967 boys, } \\
3,313 \text { girls }) \dagger\end{array}$ & $7-17$ & - HJ; & $\begin{array}{l}59.8 \% \text { of the boys } \\
(n=2,979) \\
56.3 \% \text { of the girls } \\
(n=1865)\end{array}$ & PROESP/BR $\S^{37}$ \\
\hline & & $\begin{array}{c}7,967 \\
(4,724 \text { boys } \\
3,243 \text { girls }) \ddagger\end{array}$ & & - TMB. & $\begin{array}{l}70.3 \% \text { of the boys } \\
(n=3,321) \\
63.2 \% \text { of the girls } \\
(n=2050)\end{array}$ & \\
\hline
\end{tabular}




\begin{tabular}{|c|c|c|c|c|c|c|}
\hline Authors & Local & Sample & $\begin{array}{l}\text { Age group } \\
\text { (years) }\end{array}$ & $\begin{array}{l}\text { Test to measure } \\
\text { muscle strength }\end{array}$ & $\begin{array}{l}\text { Percentage of subjects } \\
\text { classified as having ad- } \\
\text { equate muscle strength }\end{array}$ & $\begin{array}{l}\text { Reference for the } \\
\text { classification of } \\
\text { muscular strength }\end{array}$ \\
\hline Lima and Silva, ${ }^{8}$ & São José, SC & $\begin{array}{c}866 \\
\text { (406 boys, } \\
460 \text { girls) }\end{array}$ & $14-19$ & - HGS. & $\begin{array}{l}20.4 \% \text { of the boys }(n \\
=83) ; \\
14.8 \% \text { of the girls } \\
(n=68)\end{array}$ & CSEP 6 \\
\hline Silva et al., ${ }^{9}$ & $\begin{array}{c}\text { Florianópolis, } \\
\text { SC }\end{array}$ & $\begin{array}{c}636 \\
\text { (230 boys, } \\
406 \text { girls) }\end{array}$ & $14-19$ & - HGS. & $\begin{array}{c}36.5 \% \text { of the boys } \\
(n=84) \\
35.9 \% \text { of the girls } \\
(n=146)\end{array}$ & CSEP 6 \\
\hline Overallø & $\begin{array}{l}\text { All geograph- } \\
\text { ic regions } \\
\text { with at least } \\
\text { one locality }\end{array}$ & $\begin{array}{c}13,028 \\
(7,179 \text { boys, } \\
5,849 \text { girls)ll }\end{array}$ & $7-19$ & - TMB; HGS. & $\begin{array}{c}62.5 \% \\
\text { (not stratified by sex) } \\
65.9 \% \text { of the boys } \\
(n=4,729) ; \\
58.2 \% \text { of the girls } \\
(n=3,408)\end{array}$ & \\
\hline
\end{tabular}

† sample size available for the horizontal jump test; $\ddagger$ sample size available for the Medicine-ball throw test; $\S$ the categories excellent, very good, good and regular were considered as suitable; II for studies that presented more than one test to measure muscle strength (Luguetti et al.., ${ }^{16}$; Brandão et al.., ${ }^{29}$; Mello et al., ${ }^{30}$ was considered the information for the total calculation of the test that presented more subjects classified as adequate in relation to muscular strength (e.g., Medicine-ball throw test); $\uparrow$ for the calculation of the percentage of subjects with adequate muscle strength the following equation was considered: (number of subjects classified as having adequate muscle strength / number of subjects from all studies considered)* 100 ; HJ: horizontal jump; TMB: medicine-ball throw test; HGS: handgrip strength; SP: São Paulo state; SC: Santa Catarina state; MT: Mato Grosso state.

\section{DISCUSSION}

In the present review, 27 studies that investigated MS in children and adolescents were identified, and a large number of these studies were published after 20107-9,17,19-25,27-31,33,35,36, demonstrating that the subject has current research in the Brazilian scenario. Although the body of evidence regarding the cardiovascular and metabolic health benefits attributed to MS are unambiguous $^{4,5}$, it is speculated that the contemporary consolidation of recommendations for MS improvement in children and adolescents ${ }^{1}$ could justify the recent research relating MS in studies with children and adolescents.

Regarding the methodological quality of the studies included in the review, low or moderate risk of bias was identified, and no evidence from studies with a high risk of bias/low methodological quality was identified. This shows that studies in Brazil on this subject are well delineated and yield reliable results. Although MS research was the main objective of a small part of articles included in the review ${ }^{9}$, the high methodological rigor adopted by the studies gives a greater probability that the results regarding MS have not been biased, conferring valid interpretations and applications.

Approximately three out of four MS-related studies in children and adolescents in Brazil were conducted in the Southeastern and Southern regions of the country (77.7\%). In contrast, studies from the northerner region of Brazil were not identified. The strong expansion in the number of Physical Education courses in Brazil observed in the decade of $2000^{38}$, coupled with the demand for the qualification of higher education teachers, has exerted a strong pressure on the demand for graduate students. However, this scenario is not established in an equitable way in the country, 
which may have converged to the discrepancy in the number of productions in relation to MS according to the Brazilian regions ${ }^{38}$. In Brazil, 54.0\% of stricto sensu graduate programs in Physical Education are concentrated in the Southeastern, 24.3\% in the Southern, $10.8 \%$ in the Northeastern, $8.2 \%$ in the Midwestern and $2.7 \%$ in the Northern regions ${ }^{38}$.

The findings of the present review indicated a high number of tests used to measure MS. This is because there is a lack of consensus regarding the MS nomenclature and the tests used to evaluate $\mathrm{it}^{2}$. Metabolic, physiological and muscular demands involved, or the motor action necessary to perform the measurement/test are among the limiting factors for the elaboration of a "reference" method to evaluate $\mathrm{MS}$ levels". $1 \mathrm{MR}$ and repetition tests for certain percentages of $1 \mathrm{MR}$ (Ex: $50 \%$ of $1 \mathrm{MR}$ or $70 \%$ of $1 \mathrm{MR}$ ) have been used as a "benchmark" for determination of performance-related aspects; however, the HGS test with the use of manual dynamometer is another method used to investigate MS, considered valid and indicative of general $\mathrm{MS}^{2}$. In addition, $\mathrm{HJ}$ and $\mathrm{VJ}$ tests (muscle strength/explosive strength) were identified as good indicators of lower limb strength and general $\mathrm{MS}^{2}$. This variety of MS evaluation tests shows how difficult it is to compile all this information and compare the findings.

Several criteria for classification of MS values were identified in the studies included in this review. Although higher MS levels are directly associated with general health indicators in children and adolescents ${ }^{4,5}$, the results obtained in tests are difficult to interpret, given the lack of "reference" cutoffs to detect adequate or inadequate MS levels ${ }^{2}$. The criteria proposed by the Canadian Society of Exercise Physiology (CSEP) and those suggested by the Brazilian Sports Project (PROESP-BR) are among those used in studies for this classification, both elaborated with the proposition of indicating health zones and even performance ${ }^{6,37}$. Among the limitations of the classification of results through these criteria are the bases used to propose cutoffs based on normative standards (results presented in percentiles), which reflect the result of a subject in relation to the others, which do not excludes the possibility that this individual is positioned at a high percentile within that reference population and that the chances of presenting health problems or risk factors are higher or lower ${ }^{39}$. The proposal of criteria-based cutoff points is related to the achievement or not of specific values that guarantee less possibilities of developing a certain health problem, regardless of the result that this value has reached within a normative distribution, which increases the validity of the interpretation of results ${ }^{39}$. In this sense, Brazil should propose cutoff points based on health criteria for MS in order to have a more accurate overview of these inferences.

In the present study, the percentage of children and adolescents classified as having adequate MS levels according to some physical test battery ranged from $14.8 \%$ to $66.0 \%$ in girls and from $20.4 \%$ to $76.9 \%$ in boys. The great diversity of protocols and cutoffs used to measure and classify the MS results makes it difficult to compare results between surveys. Stud- 
ies performed in southern Brazil ${ }^{8,9}$ were those that presented the lowest percentage of individuals classified as having adequate MS; however, the cutoff points used to classify the MS values adopted in these studies were established based on the population of Canadian children and adolescents, different from the characteristics of the Brazilian population, which may have contributed to the difference between percentages.

When considering the results of studies conducted in Brazil, 65.9\% of boys and $58.2 \%$ of girls had adequate MS levels for health. In the population-based study of adolescents (15 to 19 years) in Canada, whose cutoff points for MS score classification were based on percentiles, $41 \%$ of boys and $52 \%$ of girls had adequate MS levels ${ }^{40}$. Other studies ${ }^{4,5}$ did not use specific cutoff points to classify MS values, but only to distribute the values obtained in MS tests into tertiles or quartiles. The monitoring of MS levels of the Brazilian pediatric population should be permanent as a health monitoring measure.

Some limitations of the results of this systematic review should be mentioned. Since the aim of the review was to identify studies that investigated MS in children and adolescents in Brazil, it should be recognized that the reviewed studies were heterogeneous in relation to the main objective, sample size, tests and instruments used to evaluate MS, making the comparison among results difficult ${ }^{9}$. Another limitation is that this review did not focus on localized muscle strength tests routinely used in physical test batteries for children and adolescents ${ }^{6,37}$. In addition, the limited number of researches whose main objective was to investigate the relationship of MS in children and adolescents is also a limitation. However, positive aspects of this review should be emphasized, such as the coverage of MS themes identified in research conducted in Brazil. The evaluation of the methodological quality of the included studies and the high number of databases used in MS investigation studies in children and adolescents in Brazil are strengths of this review.

\section{CONCLUSION}

The diversity of goals identified in MS-related studies in children and adolescents in Brazil demonstrates the importance of this physical valence in the health / performance context. However, there is need for a greater number of studies in Brazil, since information from some Brazilian regions regarding MS in children and adolescents is unknown. Moreover, although studies conducted in Brazil have identified low proportion of children and adolescents with adequate MS levels, the high number of cutoff points and tests used to classify / measure MS makes the comparison of results difficult, where greater number of surveys using tests and similar cutoff points to evaluate and classify FM are required. In addition, although the reduced proportion of children and adolescents in Brazil with adequate MS levels is similar to that identified in literature, the need for interventions aimed at increasing MS in the pediatric population is reinforced. 


\section{REFERENCES}

1. Rocha PECP. Medidas e avaliação em ciências do esporte. Rio de Janeiro: Sprint; 2000.

2. Castro-Piñero J, Artero EG, España-Romero V, Ortega FB, Sjöström M, Suni $\mathrm{J}$, et al. Criterion-related validity of field-based fitness tests in youth: a systematic review. Br J Sports Med 2009;44(13):934-943.

3. Silva DAS, Oliveira ACC. Impact of sexual maturation on upper and lower limb strength on adolescents. Rev Bras Cineantropom Desempenho Hum 2010;12(3):144-50.

4. Ortega FB, Silventoinen K, Tynelius P, Rasmussen F. Muscular strength in male adolescents and premature death: cohort study of one million participants. BMJ 2012;345:e7279.

5. Cohen DD, Gomez-Arbelaez D, Camacho PA, Pinzon S, Hormiga C, TrejosSuarez J, et al. Low Muscle Strength Is Associated with Metabolic Risk Factors in Colombian Children: The ACFIES Study. Plos One 2014;9(4):e93150.

6. The Canadian Physical Activity, Fitness and Lifestyle Approach (CPAFLA) CSEP - Health and Fitness Program's Health-Related Appraisal and Counselling Strategy: Canadian Society for Exercise Physiology; 2003.

7. Lopes W, Leite N, Silva L, Junior FM, Consentino C, Araújo C, et al. Influência da obesidade na força muscular de membros inferiores e superiores em adolescentes. Rev Bras Ativ Fís Saúde 2013;18(6):720-729.

8. Lima TR, Silva DAS. Clusters of negative health-related physical fitness indicators and associated factors in adolescents. Rev Bras Cineantropom Desempenho Hum 2017;19(4):436-49.

9. Silva DAS, Pelegrini A, Castro JAC, Lima TR, Sousa GR, Silva JMFL, et al. Low handgrip strength levels among adolescents in a city in southern Brazil. J Bodyw Mov Ther 2017;21(4):884-889.

10. National Heart L, Institute B. Quality assessment tool for observational cohort and cross-sectional studies. Bethesda: National Institutes of Health, Department of Health and Human Services. 2014.

11. Kent S, Fusco F, Gray A, Jebb SA, Cairns BJ, Mihaylova B. Body mass index and healthcare costs: a systematic literature review of individual participant data studies. Obes Rev 2017;18(8):869-79.

12. Brito CFA, Andrade DR, Araujo TL, Matsudo VKR. Estabilidade da aptidao fisica entre a infancia e a adolescencia. Rev Bras Ativ Fís Saúde1999;4(1):5-12.

13. Conte M, Gonçalves A, Aragon FF, Padovani CR. Influência da massa corporal sobre a aptidão física em adolescentes: estudo a partir de escolares do ensino fundamental e médio de Sorocaba/SP. Rev Bras Med Esporte 2000;6(2):44-9.

14. Schneider P, Rodrigues LA, Meyer F. Dinamometria computadorizada como metodologia de avaliação da força muscular de meninos e meninas em diferentes estágios de maturidade. Rev Paul Educ Fís 2002;16(1):35-42.

15. Ulbrich AZ, Bozza R, Machado HS, Michelin A, Vasconcelos IQA, StabeliniNeto A, et al. Physical fitness in children and adolescents in diferents maturacion stages. Fit Perf J 2007;6(5):277-82.

16. Luguetti CN, Nicolai AHR, Böhme MTS. Indicators of physical fitness in school children from the midwest region of Sao Paulo City. Rev Bras Cineantropom Desempenho Hum 2010;12(5):331-7.

17. Ferreira ACC, Shimano AC, Mazzer N, Barbieri CH, Elui VMC, Fonseca MCR. Grip and pinch strength in healthy children and adolescents. Acta Ortop Bras 2011;19(2):92-7.

18. Minatto G, Petroski EL, Silva DAS. Exposure to concomitant low health-related physical fitness components and associated sociodemographic factors in Brazilian adolescents. Hum Mov 2012;13(4):303-12. 
19. Arruda GA, Pianca HJC, Oliveira AR. Correlação do teste de 1RM com aspectos maturacionais, neuromotores, antropométricos e a composição corporal em crianças e adolescentes. Rev Bras Med Esporte 2011;17(3):179-83.

20. Matsudo VKR, Matsudo SM, Rezende LFM, Raso V. Handgrip strength as a predictor of physical fitness in children and adolescents. Rev Bras Cineantropom Desempenho Hum 2014;17(1):1-10.

21. Farias JP, Faria WF, Marques RGE, Antunes M, Stabelini-Neto A, Santos CF. Correlação da força muscular com indicadores antropométricos, estágio maturacional e testes neuromotores em adolescentes. Rev Bras Ciênc Mov 2015;23(2):81-8.

22. Ferrari GLM, Matsudo VKR, Fisberg M. Changes in physical fitness and nutritional status of schoolchildren in a period of 30 years (1980-2010). Rev Paul Pediatr 2015;33(4):415-22.

23. Pires AL, Soares SS, Welser L, Silva CF, Sehn AP, Kern DG, et al. Association between commuting to school and physical fitness related to motor performance in schoolchildren. Rev Epidemiol Control Infect 2017;7(3)189-193.

24. Nunes HEG, Alves-Junior CA, Goncalves ECA, Silva DAS. What Physical Fitness Component Is Most Closely Associated With Adolescents' Blood Pressure? Percept Mot Skills 2017;124(6):1107-20.

25. Silva DAS, Martins PC. Impact of physical growth, body adiposity and lifestyle on muscular strength and cardiorespiratory fitness of adolescents. J Bodyw Mov Ther 2017;21(4):896-901.

26. Biassio LG, Matsudo SMM, Matsudo VKR. Impacto da menarca nas variáveis antropométricas e neuromotoras da aptidão física, analisado longitudinalmente. Rev Bras Ciênc Mov 2004;12(2):97-101.

27. Minatto G, Nascimento TBR, Ribeiro RR, Santos KD, Petroski EL. A associacao entre a adiposidade corporal e a aptidao musculoesqueletica em meninos e mediada pelo nivel economico? Rev Bras Cineantropom Desempenho Hum 2014;16(1):116-28.

28. Barbosa JPDAS, Basso L, Seabra A, Prista A, Tani G, Maia JAR, et al. Relationship between physical activity, physical fitness and multiple metabolic risk in youths from Muzambinho's study. Eur J Sports Sci 2016;16(5):618-23.

29. Brandão CF, Fontes JHQ, Zavala AAZ, Fett WCR, Santos RJ, Fett CA. Reference index and reduction in physical fitness tests proposed by PROESP-BR. Motriz: J Phys Ed 2016;22(1):48-53.

30. Mello JB, Nagorny GAK, Haiachi MC, Gaya AR, Gaya ACA. Projeto Esporte Brasil: perfil da aptidão física relacionada ao desempenho esportivo de crianças e adolescentes. Rev Bras Cineantropom Desempenho Hum 2016;18(6):658-66.

31. Hobold E, Pires-Lopes V, Gomez-Campos R, Arruda M, Andruske CL, PachecoCarrillo J, et al. Reference standards to assess physical fitness of children and adolescents of Brazil: an approach to the students of the Lake Itaipu region-Brazil. Peer J 2017;5:e4032.

32. Linhares RV, Matta MO, Lima JRP, Dantas PMS, Costa MB, Fernandes-Filho J. Effects of sexual maturation on body composition, dermatoglyphics, somatotype and basic physical qualities of adolescents. Arq Bras Endocrinol Metab 2009;53(1):47-54.

33. Santos MM, Wellington-Barros J, Brito-Almeida M, Manhães-de-Castro R, Maia J, Góis Leandro C. Permanent deficits in handgrip strength and running speed performance in low birth weight children. Am J Hum Biol 2013;25(1):58-62.

34. Barbosa-Filho VC, Lopes AS, Bozza R, Rech CR, Campos W. Correlates of cardiorespiratory and muscular fitness among Brazilian adolescents. Am J Health Behav 2014;38(1):42-52.

35. Freitas AS, Figueiredo AJB, Freitas ALR, Rodrigues VD, Cunha AAC, Deusdará $\mathrm{FF}$, et al. Biological maturation, body morphology and physical performance in 8-16 year-old obese girls from Montes Claros - Mg. J Hum Kinet 2014;43(1):169-76. 
36. Silva SP, Beunen G, Prista A, Maia J. Short-term tracking of performance and health-related physical fitness in girls: the Healthy Growth in Cariri Study. J Sports Sci 2013;31(1):104-13.

37. Gaya APB, Silva G. Manual de aplicação de medidas e testes, normas e critérios de avaliação. Projeto Esporte Brasil; 2007.

38. Coordenação de Aperfeiçoamento de Pessoal de Nível Superior - Capes. Ministério da Educação; 2018; disponível em: https://sucupira.capes.gov.br/sucupira/public/ consultas/coleta/programa/quantitativos/quantitativoRegiao.jsf;jsessionid=IpC19 tcuSCVdbQWNHKsjYjWE.sucupira-213: [cited 2018 22/08/2018].

39. Harris J, Cale L. A review of children's fitness testing. Eur Phys Educ Rev 2006;12(2):201-25.

40. Tremblay MS, Shields M, Laviolette M, Craig CL, Janssen I, Gorber SC. Fitness of Canadian children and youth: Results from the 2007-2009 Canadian Health Measures Survey. Health Rep 2010;21(1)7-20.
CORRESPONDING AUTHOR

Diego Augusto Santos Silva Federal University of Santa Catarina, Sports Center

University campus, Trindade, Zip code: 88040-900, Florianópolis,

Brazil

E-mail: diegoaugustoss@yahoo. com.br

\section{SUPPLEMENTARY FILE}

Descriptors used in the systematic search

\section{First Block:}

English: muscle strength; Resistance Training; Muscle Contraction; weight training. muscular strength; muscular endurance; muscular power; muscular fitness; lower body explosive strength; upper body isometric strength; upper body strength; lower body strength; musculoesqueletical fitness; isometric strength; dynamic strength; isometric contraction; isotonic contraction.

Spanish: Fuerza muscular; aptitud muscular; aptitud musculoesquelética; entrenamiento de resistencia; entrenamiento con pesos; resistencia muscular; potencia muscular; fuerza de miembros inferiores; fuerza de miembros superiores; fuerza isométrica; fuerza dinámica; resistencia de fuerza;

Portuguese: Força muscular; aptidão muscular; aptidão musculoesquelética; treinamento de resistência; treinamento com pesos; resistência muscular; potência muscular; força de membros inferiores; força de membros superiores; força isométrica; força dinâmica; resistência de força; contração isotônica; contração isométrica.

\section{Second Block:}

English: Child; children; pediatric; adolescent; juvenile.

Spanish: Ninõ; preescolar; joven/adolescente; adulto joven.

Portuguese: adulto jovem; adolescentes/jovens/adolescência/juventude/ adolescente; Crianças/criança; Pré-escolar. 